\section{Dr. Donald Graham, 1914-2008}

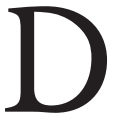

r. Donald Carter Graham had no idea nuns were so scary. One day in the I950s, while practising at St. Michael's Hospital in Toronto, Ontario, Graham brought his oldest son, also named Donald, to

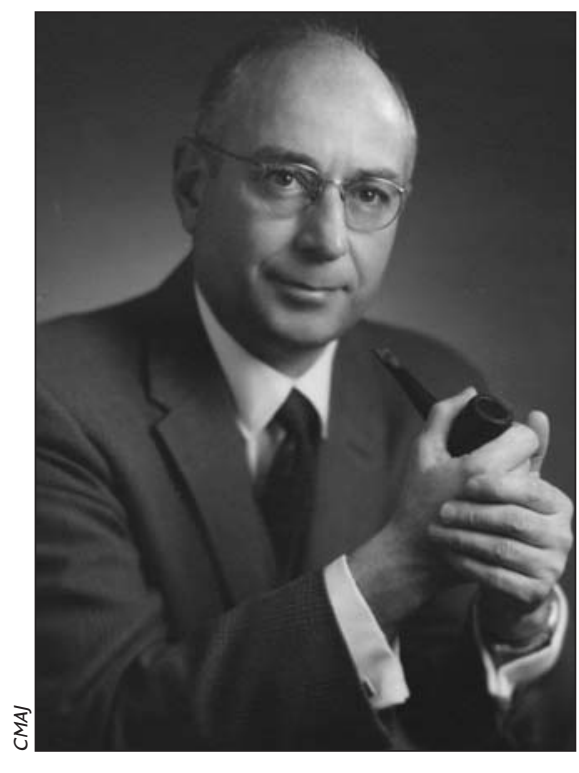

Donald Graham was editor of CMAJ from 1960 to 1965 . work. The hospital's nurses were also nuns and the boy received a fright when he laid eyes upon the habit-clad women. He thought they were witches.

"I don't think my father ever took him back," says Elizabeth Graham, chuckling as she recalls the incident.

After his days at St. Michael's, Graham joined CMAJ, then based in Toronto, where he served as editor from I96o to 1965 . He left the journal to take the position of associate dean of medicine at the University of British Columbia, where he remained until his retirement in 1979.

On Mar. 3, 2008, Graham died peacefully in his sleep in Qualicum Beach, British Columbia, at age 93. He is survived by his wife of 67 years, Winifred Graham, 9I, and his 3 children: Donald, a retired medical devices salesman; Elizabeth, a nurse; and John, a juvenile probation officer.Graham was born in Toronto on Dec. I7, I9I4. He grew up in Bolton, Ontario, where his father was a doctor. Following in his father's footsteps, Graham decided to pursue a career in medicine. He graduated from the University of Toronto's faculty of medicine in 1938 . From 1940 to 1945 , he served in the

group health insurance plans to provide equal levels of coverage for physical and mental illnesses, while prohibiting larger copayments or lower reimbursement caps for mental illnesses. The projected ro-year cost is US\$4 billion but the final tally will depend on whether legislators adopt the House of Representatives or Senate version (or some combination therein) of the legislation. Although both versions make mental health care coverage optional, the House bill is more inclusive regarding mental disorders. It also covers treatment for alcohol and drug abuse. The differences will be ironed out by a Congressional conference committee. US President George Bush has signalled opposition to the House bill, so a veto remains a possibility.

Complaints department: Health Canada has established a Food and Drugs Act Liaison Office to provide "in-
Royal Canadian Air Force, later returning to Toronto, where he completed a fellowship in internal medicine and practised at St. Michael's and Sunnybrook hospitals, specializing in rheumatoid arthritis. "His claim to fame in medical practice was his expertise of a condition called ankylosing spondylitis," says Donald. "But don't ask me how to spell that."As CMAJ editor, Graham routinely put in I6-hour days, recalls Donald. He would start work by $8 \mathrm{am}$, come home for dinner, have a quick nap and then work on his editorials until $\mathrm{I}$ or 2 in the morning. "But he found time to come to my hockey games."

After retiring, Graham obtained an honours degree in classics at age 69 . He travelled to Turkey on an archaeological expedition. He loved to swim, curl, watch baseball and tend his garden. Elizabeth also recalls how her father, who possessed a photographic memory, could multi-task like none other.

"He could sit and write while watching a football or baseball game on television and listening to a hockey game on the radio." - Roger Collier, CMAJ

DOI:Io.I503/cmaj.080496

dependent and confidential" advice to consumers with complaints about federal regulations or processes governing food and drug approval or safety.

Squires award: University of Dundee, United Kingdom, researchers Dr. Deepa Sumukadas, Miles D. Witham, Dr. Allan D. Struthers and Dr. Marion E.T. McMurdo will receive the 2007 Bruce Squires Award from CMAJ. Their study, entitled Effect of perindopril on physical function in elderly people with functional impairment: a randomized controlled trial (CMAJ 2007; I77[8]: 867-74) was "exceptional," says $C M A J$ Editor-in-Chief Dr. Paul Hébert. The award honours Editor Emeritus Dr. Bruce Squires, who served in various capacities at CMAJ from 1984 to I996, including editor-in-chief for 7 years. - Wayne Kondro, CMAJ

DOI:Io.I503/cmaj.080453 